\title{
Grade IV frostbite requiring bilateral below knee amputations: a case report

\author{
Michael J. Ramdass
}

Address: Department of Vascular Surgery, Medway Maritime Hospital, Windmill Road, Gillingham, Kent ME7 5NY, England

Email: jimmyramdass@gmail.com

Published: 8 April 2009

Cases Journal 2009, 2:6635 doi: 10.1186/147|-2180-2-6635
Received: 18 November 2008

Accepted: 3 February 2009

This article is available from: http://casesjournal.com/casesjournal/article/view/2/4/6635

(c) 2009 Ramdass; licensee Cases Network Ltd.

This is an Open Access article distributed under the terms of the Creative Commons Attribution License (http://creativecommons.org/licenses/by/3.0), which permits unrestricted use, distribution, and reproduction in any medium, provided the original work is properly cited.

\begin{abstract}
A rare case of grade IV frostbite is presented resulting in bilateral below knee amputations. This case highlights the importance of early versus late amputation as well as the importance of close collaboration between the rehabilitation, surgical, psychosocial, and public health disciplines in this rare and challenging problem that still may be encountered in the United Kingdom.
\end{abstract}

\section{Case presentation}

This is the case of a 50-year old homeless man who sustained grade IV frostbite injuries to both feet after sleeping out in sub-zero temperatures. The patient first presented with ischaemic feet with well demarcated areas around the ankle (Figure 1). The feet were left to demarcate and became mummified (Figure 2), then bilateral below knee amputations were performed.

Delayed amputation had a positive effect on psychological acceptance of bilateral amputations by the patient as well as preparation for rehabilitation.

Bilateral below-knee amputations are rarely performed. The predisposing factors include diabetic foot sepsis, atherosclerosis, frostbite, burns, trauma, calciphylaxis-related gangrene, suicide attempt, sensory loss and calf-wound healing failure after coronary revascularisation $[1,2]$. One of the main issues surrounding this problem is the justification of restorative efforts due to a high failure rate.
Frostbite can be graded into stages I to IV depending on tissue depth involvement. Two main approaches can be adopted with deep frostbite, either (a) early necrectomy with subsequent local treatment of wounds and (b) longterm conservative treatment until formation of demarcation line of necrotic tissue with subsequent resection and formation of a stump to facilitate rehabilitation.

This case highlights the importance of careful consideration of early versus late amputation as well as the importance of close collaboration between the rehabilitation, surgical, psychosocial, and public health disciplines in this rare and challenging problem that still may be encountered in the United Kingdom.

\section{Consent}

Written informed consent was obtained from the patient for publication of this case report and accompanying images. A copy of the written consent is available for review by the Editor-in-Chief of this journal. 


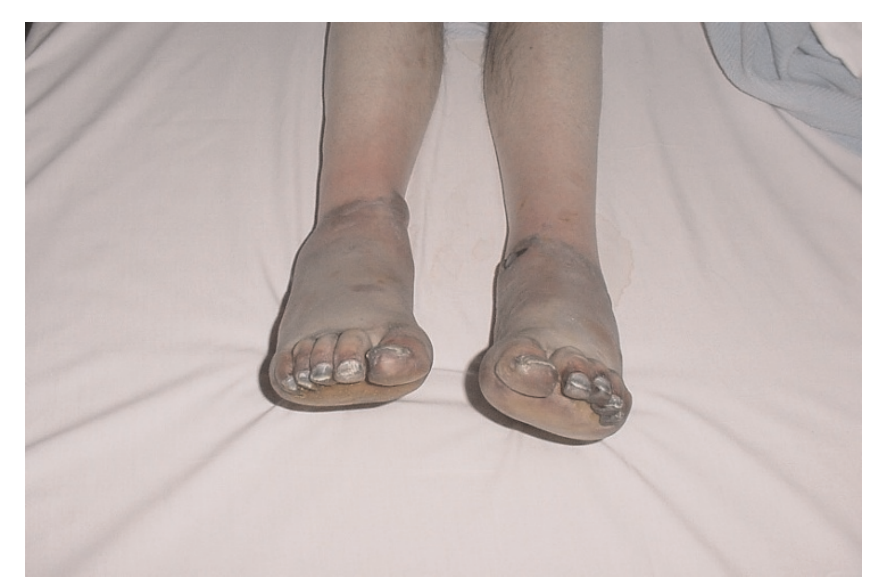

Figure I.

Initial presentation of frostbite on day 2.

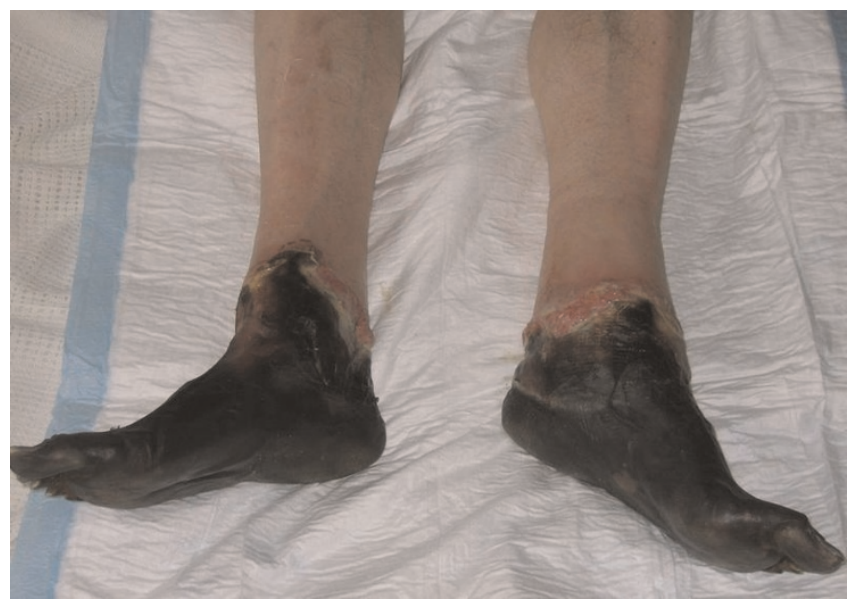

Figure 2.

Appearance of grade IV frostbite with completely mummified feet 3 weeks post-injury.

\section{Competing interests}

The author declares that he has no competing interests.

\section{Author's Contribution}

MJR is the sole author to this article and has written and researched the case himself.

\section{References}

I. Kaufman JL: Alternative methods for below-knee amputation: reappraisal of the Kendrick procedure. J Am Coll Surg. Dec 1995, I8I(6):5II-5I6.

2. Thornhill HL, Jones GD, Brodzka W, VanBockstaele P: Bilateral below-knee amputations: experience with 80 patients. Arch Phys Med Rehabil. Mar 1986, 67(3):159-163.

\section{Do you have a case to share?}

Submit your case report today

- Rapid peer review

- Fast publication

- PubMed indexing

- Inclusion in Cases Database

Any patient, any case, can teach us something

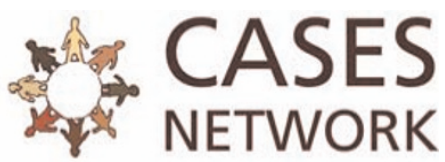

www.casesnetwork.com 